\title{
PERBANDINGAN KEMAMPUAN EKSTRAK KULIT PISANG AGUNG SEMERU DAN PISANG MAS KIRANA VARIETAS LUMAJANG DALAM MENGHAMBAT PERTUMBUHAN Candida albicans
}

\author{
Dwi Nur Rikhma Sari ${ }^{1)}$, David Kristian Susilo²) \\ ${ }^{1)}$ Pendidikan Biologi FP. MIPA IKIP PGRI Jember \\ 2)Pendidikan Ekonomi, FP. IPS IKIP PGRI Jember \\ Email: rikhmasari.dnrs@gmail.com, david.jfc12@gmail.com
}

Diterima 12 Juli 2017 disetujui 20 Agustus 2017

\begin{abstract}
Agung Semeru banana and Mas Kirana, is one of the typical banana varieties found in Lumajang Regency. Where on the banana peel extraction contain various antifungi compounds. The purpose of this research is to know the difference of banana extract of Agung Semeru and banana Mas Kirana varieties of lumajang, in inhibiting the growth of pathogenic fungi Candida albicans, and to know the optimal concentration which can inhibit the growth of Candida albicans. The method used was Completely Random Design (RAL) with four of factors, that is: $0,25,50,75$ and $100 \%$. The results were analyzed with Anova test and Duncan test multiple ranger test at the level of 5\%. Each treatment was repeated three times. The results show that there is an effect of giving extract of Semeru banana peel $(\mathrm{sig}=0,003)$ and banana Mas Kirana ( $\mathrm{sig}=$ $0,00)$ to Candida albicans growth at various concentration $(0 \%, 25 \%, 50 \%, 75 \%$ and $100 \%)$. For extract of Semeru banana peel at concentration $100 \%(38,10 \pm 16,21 \mathrm{~mm})$ showed better result from other concentration, while for banana Mas Kirana Lumajang peel extract, at concentration $100 \%(29,00 \pm 1,49 \mathrm{~mm})$ showed better result than treatment other. Ability of antifungal activity of Agung Semeru banana peel extract better than banana Mas Kirana.
\end{abstract}

Keywords: banana peel extraction, Agung Semeru, Mas Kirana,Candida albicans

\section{PENDAHULUAN}

Pisang Agung Semeru dan Pisang mas Kirana merupakan salah satu varietas tanaman pisang yang khas terdapat di Kabupaten Lumajang. Berdasarkan data produksi kebutuhan pasar di tahun 2009, produksi tanaman pisang di Kabupaten Lumajang merupakan yang terbesar, yakni 50.776,2 ton (tahun 2008) dan meningkat produksinya disetiap tahun (Fiqrotul, 2011). Kulit pisang, khususnya pisang Agung Semeru dan pisang Mas Kirana merupakan salah satu penghasil limbah buah pisang yang cukup banyak terutama pada daerah-daerah penghasil produk olahan pisang. Pada umumnya kulit pisang hanya dianggap sebagai limbah organik yang tidak mencemari lingkungan dan dimanfaatkan oleh beberapa masyarakat sebagai bahan pakan ternak (kambing, sapi, dan kerbau) (Susanti, 2006).

Kulit pisang mengandung berbagai komponen fitokimia dan berfungsi sebagai senyawa antimikroba yaitu adalah tanin dan kuinon sebagai senyawa antibakteri (Zainab et al., 2013 dalam Fadhilah 2014), senyawa alkaloid, flavonoid dan saponin (Subrata et al., 2011 dalam Fadhilah 2014), phylobattanin, antrakuinon, kuinon (Salau, et al., 2010). Senyawa antifungi dari tanaman merupakan hasil dari metabolit sekunder tanaman, yaitu golongan fenolik dan terpen dalam minyak atsiri.(Viyekanand, 2011), serta golongan alkaloid, saponin, tanin, fenolik, flavonoid dan triterpenoid (Pratiwi, 2011). 
Candida albicans merupakan salah saru flora indegenous pada saluran reproduksi, kulit, saluran pernafasan, selaput mukosa dan bersifat oportunis. (Ridawati, et al., 2011). Selain itu, Candida albicans juga dapat menginfeksi dan bersifat patogen pada berbagai daerah tertentu antara lain pada gigi (Putri, et al., 2011). Berbagai jenis pengobatan yang digunakan sebagai agen antifungi akibat infeksi Candida albicans telah banyak dilakukan, antara lain adalah golongan polyene, golongan imidazole, golongan triazole, golongan echinocandins (Bormann and Morrison, 2009; Mario et al., 2012; Coelho, et al,2012), nystatin yang diduga sangat efektif dalam mengobati penyakit yang disebabkan oleh Candida albicans (Coelho, et al, 2012). Penggunaan obat obat kimiawi tersebut mengakibatkan mikroorganisme menjadi resisten dan semakin sulit untuk diobati. Sehingga diperlukan suatu akternatif lain yang lebih aman dan membuat mikroorganisme tidak resisten, yaitu menggunakan senyawa antikroba yang terdapat dari ekstrak suatu tanaman.

Tujuan penelitian ini adalah untuk mengetahui perbedaan kemampuan ekstrak kulit pisang Agung Semeru dan kulit pisang Mas Kirana varietas Lumajang dalam menghambat pertumbuhan fungi patogen Candida albicans, serta mengetahui konsentrasi optimal yang dapat menghambat pertumbuhan Candida albicans.

\section{METODE}

\section{Sterilisasi Alat dan Bahan}

Sterilisasi dalam penelitian ini yaitu alat-alat dan bahan berupa Media PDA yang akan digunakan untuk pengujian antimikroba. Proses sterilisasi menggunakan autoklaf pada suhu $121^{\circ} \mathrm{C} 1$ atm dengan waktu 15 menit. Uap air ini akan mengkoagulasi protein penyusun dinding sel mikroba seperti bakteri sehingga bakteri dalam alat dan media yang disterilkan tersebut akan mati

\section{Ekstraksi Kulit Pisang}

Kulit pisang Agung Semeru dan kulit pisang Mas Kirana varietas Lumajang dibersihkan dan diblender hingga halus kemudian dimaserasi. Sebanyak 100 gram kulit pisang Agung Semeru dan kulit pisang Mas Kirana varietas Lumajang yang telah dihaluskan dimaserasi dengan $300 \mathrm{ml}$ air selama 1 X 24 jam. Ekstrak yang diperoleh disaring dengan corong Buchner menggunakan vakum dan filtrat yang diperoleh diuapkan dengan rotary vacuum evaporator hingga didapat ekstrak kental. Agar diperoleh ekstrak kulit pisang dalam jumlah banyak proses ekstraksi dilakukan sebanyak enam kali (Supriyanti et al., 2015).

\section{Pembuatan Media Potatoes Dextrose Agar (PDA)}

Adapun pembuatan media Potatoes Dextrose Agar (PDA) $39 \mathrm{~g} / \mathrm{L}$ untuk fungi adalah memasukkan media PDA sebanyak 3,9 gram ke dalam gelas Beaker yang berisi $100 \mathrm{ml}$ akuades. Setelah itu, dipanaskan di atas kompor listrik sampai semua bahan terlarut sempurna. PDA dimasukkan ke dalam tabung reaksi masing-masing $5 \mathrm{ml}$ dan ditutup rapat dengan kapas dan melapisi dengan aluminium foil, disterilisasi dengan autoclave 1 atm, 121 ${ }^{\circ} \mathrm{C}$ selama 15-20 menit. Setelah tabung steril, selanjutnya meletakkan tabung reaksi tersebut dalam posisi miring.

\section{Pengujian Aktivitas Ekstrak}

Pada uji aktivitas ekstrak kulit pisang dilakukan sesuai dengan rancangan percobaan yang telah dibuat dan dilakukan dengan menggunakan metode difusi kertas cakram steril. Adapun tahapannya sebagai berikut : Penuangan media SDA steril yang telah dibuat sebelumnya kedalam cawan petri steril kemudian didiamkan hingga memadat; Penanaman jamur Candida albicans pada media PDA dengan menggunakan metode streak plate 
yakni hasil peremajaan Candida albicans diambil sebanyak satu ose kemudian digoreskan pada media PDA dalam cawan petri. Pemberian sampel pada kertas cakram steril untuk masing-masing konsentrasi ekstrak masing-masing perlakuan $(0 \%, 25 \%, 50 \%, 75 \%$ dan $100 \%)$. Peletakkan kertas cakram steril yang sudah mengandung sampel, kontrol positif, dan kontrol negatif ke dalam media suspensi jamur Candida albicans. Selanjutnya diinkubasi selama 1-2 hari pada suhu ruang. Pengamatan hasil dilakukan dengan mengukur diameter zona hambat yang terbentuk disekeliling kertas cakram yang ditanam pada suspensi jamur Candida albicans.

\section{Analisis Data}

Data yang diamati meliputi diameter zona hambat ekstrak kulit pisang agung semeru dan pisang Mas Kirana varietas Lumajang akan dianalisis secara kuantitatif menggunakan SPSS 20. Data hasil pengamatan akan dianalisis dengan menggunakan ANOVA faktorial 5\% dan dilanjutkan dengan uji Duncan's multiple range test (DMRT) untuk membandingkan antar perlakuan. Dimana sebelum dilakukan uji ANOVA, data terlebih dahulu diuji Normalitas dan uji Homogenitas

\section{HASIL DAN PEMBAHASAN}

Penelitian ini bertujuan untuk mengetahui perbedaan aktivitas antimikroba dari ekstrak kulit pisang Agung Semeru varietas Lumajang dalam menghambat pertumbuhan fungi Candida albicans. Berdasarkan hasil penelitian, menunjukkan bahwa ekstrak kulit pisang Agung Semeru varietas Lumajang dan ekstrak kulit pisang Mas Kirana Lumajang pada berbagai konsentrasi $0 \%, 25 \%$, $50 \%, 75 \%$ dan $100 \%$ dapat menghambat pertumbuhan fungi patogen Candida albicans (tabel 1). Berdasarkan hasil analisis statistika yang menggunakan uji ANOVA taraf kepercayaan 5\% menunjukkan adanya signifkan antar perlakuan baik untuk ekstrak kulit pisang Agung Semeru $(\alpha=0,003)$ maupun ekstrak kulit pisang Mas Kirana ( $\alpha$ $=0,000)$ (Gambar 1 dan 2), dimana perlakuan terbaik untuk ekstrak Pisang Agung Semeru varietas Lumajang terdapat pada perlakuan dengan konsentrasi $100 \%\left(38,10 \pm 16,21^{\mathrm{c}}\right)$ sedangkan untuk perlakuan ekstrak Pisang Mas Kirana Lumajang terdapat pada perlakuan dengan konsentrasi 100\% $\left(29,00 \pm 1,49^{\circ}\right)$ (tabel 1).

ANOVA

Diameter Zona Hambat Candida albicans

\begin{tabular}{|l|r|r|r|r|r|}
\hline & \multicolumn{1}{|c|}{$\begin{array}{c}\text { Sum of } \\
\text { Squares }\end{array}$} & df & Mean Square & F & Sig. \\
\hline Between Groups & 2607,687 & 4 & 651,922 & 8,575 &, 003 \\
Within Groups & 760,287 & 10 & 76,029 & & \\
Total & 3367,973 & 14 & & & \\
\hline
\end{tabular}

Gambar 1. Hasil tes statistika menggunakan uji ANOVA 5\% untuk Pisang Agung Semeru Lumajang 


\section{ANOVA}

Diameter Zona Hambat Candida albicans

\begin{tabular}{|l|r|r|r|r|r|}
\hline & $\begin{array}{c}\text { Sum of } \\
\text { Squares }\end{array}$ & df & Mean Square & \multicolumn{1}{c|}{ F } & Sig. \\
\hline Between Groups & 1613,151 & 4 & 403,288 & 74,159 &, 000 \\
Within Groups & 54,381 & 10 & 5,438 & & \\
Total & 1667,533 & 14 & & & \\
\hline
\end{tabular}

Gambar 2. Hasil tes statistika menggunakan uji ANOVA 5\% untuk Pisang Mas Kirana Lumajang

Tabel 1. Diameter zona hambat ekstrak kulit pisang Agung Semeru; Esktrak Kulit Pisang Mas Kirana varietas Lumajang terhadap pertumbuhan Candida albicans

\begin{tabular}{ccc}
\hline & \multicolumn{2}{c}{$\begin{array}{c}\text { Rata-Rata Diameter Zona } \\
\text { Hambat Candida albicans } \\
\text { Konsentrasi } \\
\text { Ekstrak (\%) }\end{array}$} \\
\cline { 2 - 3 } & $\begin{array}{c}\text { Pisang Agung } \\
\text { Semeru }\end{array}$ & $\begin{array}{c}\text { Pisang Mas } \\
\text { Kirana }\end{array}$ \\
\hline 0 & $0,00 \pm 0,00^{\mathrm{a}}$ & $0,00 \pm 0,00^{\mathrm{a}}$ \\
25 & $16,15 \pm 3,39^{\mathrm{b}}$ & $16,22 \pm 0,30^{\mathrm{b}}$ \\
50 & $20,10 \pm 5,83^{\mathrm{b}}$ & $20,83 \pm 4,49^{\mathrm{b}}$ \\
75 & $31,56 \pm 8,47^{\mathrm{bc}}$ & $27,30 \pm 0,41^{\mathrm{c}}$ \\
100 & $38,10 \pm 16,21^{\mathrm{c}}$ & $29,00 \pm 1,49^{\mathrm{c}}$ \\
\hline
\end{tabular}

Pada Tabel 1 menunjukkan bahwa, untuk ekstrak kulit pisang Agung Semeru Lumajang maupun ekstrak kulit pisang Mas Kirana Lumajang menujukkan adanya pengaruh signifikan terhadap pertumbuhan Candida albicans, dan menunjukkan semakin tinggi konsentrasi yang diberikan maka semakin besar pula diameter zona hambat pertumbuhan Candida albicans dengan konsentrasi terbesar dalam menghambat pertumbuhan yaitu 100\%. Meskipun demikian, perlakuan pemberian konsentrasi ekstrak kulit pisang dapat menghambat pertumbuhan Candida albicans yang ditandai dengan adanya perbedaan perlakuan dengan kontrol negatif (tanpa perlakuan).

Pada tabel 1, untuk pemberian ekstrak kulit pisang Agung Semeru menunjukkan bahwa perlakuan dengan konsentrasi $25 \%$ $\left(16,15 \pm 3,39^{\mathrm{b}}\right), 50 \%\left(20,10 \pm 5,83^{\mathrm{b}}\right)$, $75 \%\left(31,56 \pm 8,47^{\mathrm{bc}}\right)$ dan $100 \%(38,10$ $\left.\pm 16,21^{\mathrm{c}}\right)$ menunjukkan hasil yang lebih baik dibandingkan dengan kontrol $(0,00$ $\left.\pm 0,00^{\mathrm{a}}\right)$, dengan perlakuan konsentrasi $100 \%$ menunjukkan hasil yang lebih baik dengan ditandai diameter zona hambat pertumbuhan Candida albicans yang lebih besar. Untuk perlakuan pemberian ekstrak kulit pisang Mas Kirana juga menunjukkan hasil yang lebih baik untuk konsentrasi $\left.25 \%\left(16,22 \pm 0,30^{\mathrm{b}}\right), 50 \% 20,83 \pm 4,49^{\mathrm{b}}\right)$, $75 \%\left(27,30 \pm 0,41^{\mathrm{c}}\right)$ dan $100 \%(29,00 \pm$ $\left.1,49^{\mathrm{c}}\right)$ dibandingkan dengan perlakuan kontrol $\left(0,00 \pm 0,00^{\mathrm{a}}\right)$, dengan perlakuan konsentrasi $100 \%$ menunjukkan hasil yang lebih baik dalam menghambat pertumbuhan Candida albicans.

Berdasarkan pada tabel 1 menunjukkan bahwa pemberian ekstrak kulit Pisang Agung Semeru Lumajang dan pisang Mas Kirana Lumajang mampu menghambat pertumbuhan Candida albicans dibandingkan dengan perlakuan kontrol negatif. Hal ini menunjukkan bahwa ekstrak kulit pisang Agung Semeru maupun pisang Mas Kirana bersifat sebagai senyawa antifungi terhadap fungi Candida albicans. Hal ini sesuai dengan penelitian yang telah dilakukan sebelumnya, tentang uji fitokimia pada ekstrak kulit pisang Agung Semeru dan kulit pisang Mas Kirana, dimana ekstrak kulit pisang tersebut menunjukkan hasil positif untuk senyawa fenolik/Alkaloid, senyawa terpen dan senyawa saponin.

Hal ini sesuai dengan penelitian yang telah dilakukan oleh Permatasari (2013), bahwa senyawa saponin pada ekstrak kulit pisang berperan sebagai senyawa antimikroba yang bekerja dengan mengganggu permeabilitas membran sel 
sehingga mengakibatkan kerusakan dan keluarnya berbagai komponen penting yang ada di dalam sel seperti protein, asam nukleat, nukleotida dan lain-lain. Selain itu, senyawa saponin juga dapat mengikat ergosterol (Gang, 2011) yang dapat memicu terjadinya peningkatan permeabilitas membran sel dan sel mengalami kebocoran komponen penting sel sehingga mengakibatkan sel jamur lebih mudah mati (Gubbins dan Anaisse, 2007). Selain itu, pada kulit pisang juga mengandung senyawa alkaloid dan tanin, untuk senyawa alkaloid bekerja melubangi membran sel sel fungi yang menyebabkan sel fungi menjadi lemah (Arif, et al., 2009) dan untuk senyawa tannin bekerja dalam menghambat sintesis komponen penting pada dinding sel jamur (kitin) yang berfungsi untuk melindungi sel jamur dari intraseluler (Watson and Preedy, 2008) sehingga akan menyebabkan masuknya air, nutrisi, dan enzim yang tidak terseleksi (Hayati et al., 2009).

Untuk ekstrak kulit pisang Agung Semeru Lumajang pada konsentrasi $100 \%$ memiliki aktifitas antifungi dan menunjukkan hasil yang lebih baik dalam menghambat pertumbuhan Candida albicans dibandingkan dengan diameter yang terbentuk untuk ekstrak pisang Mas Kirana (tabel 1). Perbandingan perbedaan aktifitas antifungi pada ekstrak kulit pisang Agung Semeru dan pisang Mas Kirana varietas Lumajang menunjukkan bahwa ekstrak kulit pisang Agung Semeru mampu menghambat pertumbuhan Candida albicans yang ditandai dengan lebarnya diameter zona hambat bila dibandingkan dengan seluruh perlakuan berbagai konsentrasi baik pada ekstrak kulit pisang Agung Semeru maupun pada ekstrak kulit pisang Mas Kirana. Hal ini, dapat disebabkan karena berdasarkan hasil uji fitokimia yang telah dilakukan menunjukkan bahwa ekstrak kulit pisang Mas Kirana memiliki kandungan senyawa alkaloid sedangkan pada kulit pisang Mas
Kirana menunjukkan hasil negatif untuk senyawa alkaloid, sehingga kulit pisang Agung Semeru lebih mampu menghambat pertumbuhan Candida albicans dengan sangat baik (Sari dan Susilo, 2017). Senyawa alkaloid yang terdapat pada ekstrak kulit pisang Agung Semeru Lumajang, bersifat sebagai antifungi yang bekerja dengan cara mengganggu komponen penyusun dinding sel sehingga lapisan penyusun dinding sel tidak terebentuk secara sempurna yang akan menyebabkan sel mengalami kematian, selain itu komponen alkaloid juga diketahui sebagai interkelator DNA dan menghambat enzim topoisomerase (Karou et al., 2005).

\section{SIMPULAN}

Pemberian ekstrak kulit pisang Agung Semeru $(\operatorname{sig}=0,00)$ dan kulit pisang Mas Kirana $(\operatorname{sig}=0,00)$ pada berbagai konsentrasi $(0 \%, 25 \%, 50 \%$, $75 \%$ dan $100 \%$ ) menunjukkan hasil yang signifikan berpengaruh nyata terhadap pertumbuhan fungi Candida albicans. Untuk ekstrak pisang Agung Semeru konsentrasi $100 \%$ dan ekstrak pisang Mas Kirana 100\% menunjukkan hasil lebih baik daripada perlakuan konsentrasi yang lain yang ditunjukkan dengan besarnya diameter zona hambat pertumbuhan Candida albicans.

\section{DAFTAR PUSTAKA}

Arif T, Bhosale JD, Kumar, Naresh, Mandala TK, Bendre RS, Lavekar GS and Rajesh Dabur. Natural Products - Antifungal Agents Derived From Plants. Journal of Asian Natural Products Research. 2009; 7(7):621-638.

Bormann, A.M. dan Morrison, V.A., 2009, Review of the pharmacology and clinical studies of micafungin. Journal ofDrug Design, Development and Therapy, 3: 295-302 
Coelho, J.M, Claudino, A.L.R., Chavasco, J.M., Birman, E.G., Gambale, W., Aleva, N.A., Dias, A.L.T., Paula, C.R., dan Chavasco, J.K., 2012, Antifungal susceptibility evaluation of Candida albicans isolated from buccal lesions of hiv-positive and HIV-

Fadhilah, Fairuz Mohd Jalano, Suharni Mohamad, wan Nazatul Shima Shahidan. 2014. Antibacterial effect of banana pulp extracts based on different extractio methods againts selected microorganisms. Asian Journal of Biomedical and Pharmaceutical Science: 04 (36); 2014, 14-19

Fiqrotul. 2011.Pemanfaat limbah kulit pisang (Musa sp.) menjadi Tepung Pisang di kecamatan KlakahLumajang.Posted by FIQROTUL on SEPTEMBER 15, $2011 \mathrm{https} / / /$ fiqrotul.wordpress.com/2011/09/15/ pemanfaat-limbah-kulit-pisangmusa-sp-menjadi-tepung-pisang-dikecamatan-klakah-lumajang/

Gang DR. The Biological Activity of Phytochemicals. Washington: Springer. 2011.

Gubbins PO, Anaissie EJ. Antifungal Therapy. Section One: General Principles, Inclusing Diagnosis. 2007

Hayati EK, Jannah, Fasya AG. Aktifitas Anti Bakteri Komponen Tanin Ekstrak Daun Belimbing Wuluh (Averrhoa blimbi L) sebagai Pengawet alami. Laporan Penelitian Kuantitatif Depag. Jakarta: Departemen Agama. 2009.

Karou, D., Savadogo, A., Canini, A., Yameogo, S., Montesano, C., Simpore, J., Traore, A. S. (2005). Antibacterial activity of alkaloids from Sida acuta. African Journal of Biotechnology, 4(12), 195-200.

Kawamura, F., Shaharuddin, N.A., Sulaiman, O.,Hashim, R., and
Ohara, S., 2010, Evaluation on Antioxidant Activity, Antifungal Activity ant Total Phenol of 11 Selected Commercial Malaysian Timber Species, JARQ 44 (3), 319324

Mario, D. A.N., Denardi, L. B., Bandeira, L. A., Antunes, M. S., Santurio, J. M., Severo, L. C., Alves, S. H., 2012, The activity of echinocandins, amphotericin B and voriconazole against fluconazole-susceptible and fluconazoleresistant Brazilian Candida glabrata isolates. Memórias do Instituto Oswaldo Cruz, 107

Permatasari, Gusti Ayu, I Nengah K.B, Hapsari Mahatmi, 2013. Daya Hambat Perasan Daun Sirsak Terhadap Pertumbuhan Bakteri Escherichia coli, Indonesia Medicus Veterinus, Fakultas Kedokteran Hewan Universitas Udayana, Bali.

Pratiwi, S.I.R. (2011). Karakterisasi Simplisia dan Uji Aktivitas Antioksidan Ekstrak n-Heksan, Etil Asetat, dan Etanol Herba Labu Siam (Sechium edule (Jacq.) Sw.) dengan Metode DPPH. Skripsi. Medan: Fakultas Farmasi USU.

Putri N, Ramatri D, Sugiartati R, Deviyanti $\mathrm{S}$, dan Abraham S. Uji in vitro Anti Jamur Candida albicans dari Minuman Kemasan Yoghurt dan Kedokteran Gigi

Salau, B.A., Ajani, E.O., Akinlolu, A.A., Ekor, M.N., dan Soladoye, M.O., 2010. Methanolic Extract of Musa sapientum Sucker Moderates Fasting Blood Glucose and Body Weight of Alloxan Induced Diabetic Rats. ASIAN J.EXP.BIOL.SCI., Vol I(I)2010. Hal: 30-35.

Sari, D.N.R., Susilo, D.K., 2017. Analisis Fitokimia Senyawa Antimikroba Pada Ekstrak Kulit Pisang Agung Semeru Dan Pisang Mas Kirana Varietas Lumajang. Jurnal : Bioma. Universitas Muhammadiyah Jember. Vo.2/No.2. 
Sari, dkk

Susanti,Lina. 2006. Perbedaan Penggunaan Jenis Kulit Pisang Terhadap Kualitas Nata. Skripsi Sarjana Universitas Negeri Semarang. Semarang.

Vivekanand, P. Dwivedi, N. Pareek, RP Singh. 2011. Banana peel: a potential substrates for laccase production by
Aspergillus fumigatus $\mathrm{VkJ} 2.4 .5$ in solid-state fermentation. Applied Biochemistry and Biotechnology 165 (1), pp. 204-20

Watson RR, Preedy VR. Botanical Medicine in Clinical Practice. London: Cromwell Press. 2008. 